TEME, г. XLIII, бр. 2, април - јун 2019, стр. 309-326

Оригинални научни рад https://doi.org/10.22190/TEME180131021N

Примљено: 31. 1. 2018.

UDK 796-053.4

Ревидирана верзија: 3. 3. 2018.

Одобрено за штампу: 2. 11. 2018.

\title{
NEIGHBOURHOOD SAFETY AND PHYSICAL ACTIVITY OF PRESCHOOL CHILDREN IN SERBIA: MODERATING ROLE OF A CHILD'S GENDER AND PARENTS' AGE ${ }^{a}$
}

\author{
Stefan Ninković, Stanislava Marić Jurišin, Borka Malčić* \\ University of Novi Sad, Faculty of Philosophy, Department of Pedagogy, \\ Novi Sad, Serbia \\ *borka.malcic@ff.uns.ac.rs
}

\begin{abstract}
The aim of study was to investigate the effects of parents' perceptions of neighborhood safety on outdoor physical activities of preschool children. This was investigated based on a moderating role of a child's gender and parents' age. The results showed that the association of parents' perceptions of neighborhood safety on outdoor physical activities of children depended of the child's sex and the parents' age. Boys whose parents were younger and who positively assessed the neighborhood safety were more inclined to outdoor physical activities. Female children whose parents were below the average age the perceived neighborhood safety hindered frequent outdoor playing. The paper discusses practical implications of the obtained results and recommendations for future research.
\end{abstract}

Key words: neighborhood safety; parent's age; child's sex; physical activity, preschoolers.

\section{БЕЗБЕДНОСТ СУСЕДСТВА И ФИЗИЧКА АКТИВНОСТ ДЕЦЕ ПРЕДШКОЛСКОГ УЗРАСТА: МОДЕРАТОРСКА УЛОГА ПОЛА ДЕТЕТА И СТАРОСТИ РОДИТЕЉА}

\footnotetext{
Апстракт

Циљ овог рада био је испитивање ефеката родитељских перцепција безбедности суседства на физичку активност деце предшколског узраста у Србији. Приликом истраживања овог односа, анализирана је модераторска улога пола деце и старости родитеља. Резултати показују да перцепција родитеља о безбед-

${ }^{a}$ The paper is the result of research conducted in the framework of the project "Quality of educational system in Serbia in European perspective (KOSSEP)" (No. 179010), funded by the Ministry of Science and Technological Development of Republic of Serbia.
} 
ности суседства физичке активности деце на отвореном зависи од пола деце и година родитеља. Анализа модериране модерације показала је да су дечаци предшколског узраста који имају млађе родитеље који позитивније процењују безбедност суседства склонији физичкој активности на отвореном. С друге стране, у случају деце женског пола чији родитељи су исподпросечне старости, опажена безбедност краја не предвиђа учесталост играња на отвореном. У раду се разматрају практичне импликације добијених резултата и дискутује се о препорукама за будућа истраживања.

Кључне речи: безбедност суседства, године родитеља, пол детета, физичка активност, предшколци.

\section{INTRODUCTION}

The child's early years of life are crucial in setting up some foundations for its further development. From the time of conception until the first day of school, the development is constant and goes through various biological and social forms. It is a period in which the brain still develops intensively, and children acquire the ability to speak, think, learn and correctly develop their body. Confluent physical growth and development requires meeting certain general conditions, such as proper nutrition, clean air, ample sunshine, adequate hygiene, physical activities, playing and interacting with peers and adults.

With the growing differences in financial and social terms between the "natural" ambience and urban environment in which people live today, physical activities are becoming increasingly important. Taking into consideration that the urban environment imposes a lot of limitations on one side, and offers a lot of comforts on the other side, there is a decreased need for moving, and therefore, increased possibilities for unbalanced growth and development, occurrence of limb deformities in children, obesity and unbalanced development of the nervous system. Therefore the pedagogical imperative is a request to overcome the adverse impacts (such as: unbalanced nutrition, water and air pollution, harmful radiation of the Sun and insufficient exposure to the Sun, inappropriate hygiene, decreased possibilities for moving and play) in order to accomplish the balanced physical growth and development, as well as the improvement of body and mental health of the preschool children (Kamenov, 2006).

Contemporary experts dealing with this issue commonly believe that pursuing physical activities positively affects the achievement of optimum health in many ways, respecting also a healthy diet and a balanced body weight (Hill and Peters, 1998; Wardle et al., 2001; Harris et al., 2009; Zecevic et al., 2010). Physical activities are particularly important for children, because they directly influence the development of motor skills necessary for academic performances, as well as self-control, self-esteem and socio-emotional maturation (Emck et al., 2009). Accordingly, it can be 
clearly concluded that physical activity significantly affects social, mental and physical development of children (Carlin et al., 1997; Boreham and Riddoch, 2001; Tomkinson et al., 2003). Physical activity in groups and games has also social benefits, providing children with the opportunity to master new skills, while developing friendships with peers (Bailey, 2005).

In the era of exaggerated urbanization, alienation and domination of mass media, increasingly fewer children spend their time practicing outdoor physical activity (Hill and Peters, 1998). Many studies have found neighborhood safety to be a potential barrier for practicing outdoor physical activities (Carver et al., 2008; Datar et al., 2013). Neighborhood safety represents a potentially important, yet under-researched factor of social environment, which affects the physical activity of children. Based on the current knowledge, neighborhood safety evidently affects the overall physical activities of children, particularly outdoor physical activity, since the time spent outdoors is considered one of the most important correlates of physical activity of preschool children (Klesges et al., 1990; Sallis et al., 1993). Neighborhood safety and the safety of location where the activities take place are among the primary factors of parental perception when selecting sites for playing and practicing physical activities (Carver et al., 2008; Carver et al., 2010; Datar et al., 2013; Weir et al., 2006). Although current findings consistently indicate that parental beliefs about neighborhood safety affect the nature of the neighborhood children's play and outdoor physical activities, it is important to examine the potential moderators of this relation. In addition, due to the lack of similar studies in Serbia, it is important to examine how parental perceptions of neighbourhood safety in this country affect the physical activity of preschool children.

\section{Theoretical Background - "Sporty kids" instead of "Rainy day kids"}

Physical activity at the earliest age provides physical, cognitive and affective benefits to the overall development of the child. It reduces the risk factors for the development of various heart diseases and obesity, increasingly widespread in children. Physical activities help building strong muscles in children and promote mental health, which in turn reduces anxiety and depression, and creates a stable basis for the general good mental and physical condition of the body (Sturza Milic, 2008).

Health and education authorities of many developed countries have issued a recommendation which emphasizes that children need to spend at least one hour a day practicing moderate to high level of physical activity (Australian Department of Health and Ageing, 2004; National Association for Sport and Physical Education, 2004; Strong et al., 2005; Carver et al., 2008; Okely et al., 2009). Physical activity of children of preschool age usually does not occur as a planned and structured activity. Children are practicing it in different contexts, for example, on the playground or 
engaging in a direct game, thus contributing to the cognitive, physical, social and emotional growth and development (Hinkley et al., 2008).

One of the primary features of preschool children is that they are very active, with physical activities being the essential factor in meeting their needs for exercise and mobility. These activities play a significant role in improving the child's muscle coordination, strength and flexibility (Atan et al., 2013). Playing and engaging in physical activity (running, jumping, swinging, seesawing, climbing, cycling, skating, etc.) the child becomes healthier and happier.

An increasing number of preschool children ( 3 to 5 years old) spend more time in using electronic media (television, computers, video games, etc.), than being engaged in physical activities (Pate et al., 1996; Certain and Kahn, 2002). Such children are called 'indoor kids' or 'rainy day kids" (Tandy, 1999; Karsten, 2005; Carver et al., 2008; Grigsby-Toussaint et al., 2011) by some authors. Reviewing the available research, it can be concluded that boys are more active than girls, and that they spend more time in dynamic outdoor games, while girls spend more time playing indoors where the game is more static. A study conducted by Đorđić (Đorđić, 2006) confirmed that, taking into account the total number of hours that preschool children weekly spent in physical activities, boys were significantly more physically active than girls. This is especially true of locomotors activity (almost 2 hours a week in favor of boys), and ball activities (1.5 hours a week in favor of boys). Only balance-type exercises (activities) were more prevalent in girls.

Preschool girls also spend more time watching TV than boys, and both spend insufficient time in pursuing outdoor physical activities (Cherney and London, 2006; Hinkley et al., 2008; Zecevic et al., 2010). According to the National Association for Sport and Physical Education, it has been recommended for the preschool children to have 60 minutes of structured (organized) physical activities and 60 minutes of unstructured (informal) physical activities per day (Zecevic et al., 2010). These results could potentially be interpreted in the light of traditional upbringing in relation to gender stereotypes where boys are expected to be more physically active than girls (Ginsburg, 2007). This is confirmed by the results of numerous studies (Sturza Milic, 2008), suggesting that, on the average, boys' parents encourage physical activity of their child significantly more than girls' parents. Also, they favor boys over girls with certain actions. This means that parents are treating boys and girls differently when it comes to encouraging their participation in physical activities. Unfortunately, a general conclusion is that more preschool children can be classified into 'rainy day' than 'sporty' category, regardless of their gender. 


\section{Neighborhood Safety and Children's Physical Activity}

Physical activity of children outdoors provides parents with the opportunity to fully engage in play with their children. However, in spite of the benefits that the game offers to parents and children, the time and opportunity for free play have been significantly reduced for some children (Ginsburg, 2007). Since parents are identified as carriers of children's physical activation, and their level of care can significantly affect the opportunity children have to freely play, a number of studies have been carried out to analyze the factors that the parents take into account when choosing a place for children's play and physical activity in general (Sallis et al. 1997). Parental perceptions are influenced by many factors, including the actual level of crime in the neighborhood, the numerous disadvantages of the neighborhood where the children live (e.g. socio-economic conditions, social relationships), individual characteristics (e.g. gender, age, socio-economic status, previous negative experiences), and media propaganda (Datar et al., 2013).

Neighborhood safety, traffic, availability of toilets, drinking water, and lighting are dominant factors identified in the above studies (Hillman et al., 1990; Blakely, 1994; Evans, 2000; Tranter and Pawson 2001; Mullan, 2003; Davison and Lawson, 2006; Carver et al., 2008; Carver et al., 2010; Veitch et al., 2006; Weir et al., 2006). Taking into account the analyzed studies, neighborhood is the most frequently quoted and highlighted factor in the context of physical activity for several reasons. First, the neighborhood is crucial for children's outdoor play, and it is proven that the time children spend outdoors can be taken as a significant determinant of the overall physical activity of children (Carver et al., 2008; Klesges et al., 1990; Sallis et al., 1993). Second, the neighborhood provides opportunities for inexpensive forms of physical activity (e.g. walking, cycling, skating ...), which can be especially important in the communities, regions and countries of low socio-economic status (Humbert et al., 2006). Physical activities in the neighborhood are available to children constantly, without being necessary for parents to provide additional transport for them, and thus spend extra time and money so that the children can take physical activities.

Neighborhood safety is a complex phenomenon and can be treated in many ways depending on the essential elements that define it, such as a fear of strangers who are perceived as a threat ("stranger danger"), physical injuries, road safety and bullying. Studies dealing with parental worries and fears for the safety of their children emphasize that road safety and "stranger danger" are the key factors for parents (Carver et al., 2008; Hillman et al., 1990; Matthews, 1995; Valentine and McKendrick, 1997; Burman et al., 2000; Tranter and Pawson, 2001; Mullan, 2003; Timperio et al., 2004).

Analyzing studies dealing with parental perceptions of the neighborhood as a predictor of practicing outdoor physical activities of children it is evident that children living in "green" neighborhoods have more 
opportunities to stay outdoors and engage in physical activities (GrigsbyToussaint et al., 2011), as well as children of parents who are themselves engaged in physical activities (Hinkley et al., 2008). It is also interesting that the parents' age is negatively correlated with the level of physical activity in preschool children, while parental income and the level of education do not show any significant correlation (Zecevic et al., 2010). Unfortunately, previous studies on the subject have rarely discussed the role of parents' age, although there have been reports that the parents' upbringing practices are influenced by their age.

The aim of this study is to examine the effects of parent perceptions of neighborhood safety on the level of physical activity in preschool children. In addition, while examining this prediction, moderating role of the child's gender and parents' age will also be taken into account. Previous studies have shown that the parental assessment of neighborhood safety is a consistent factor for physical activity in preschool children. On the other hand, current findings suggest that the boys of preschool age are more physically active than girls of the same age, while the role of the parents' age is less known. This research is focused on examining the effects of interaction between the characteristics of parents (perceptions of neighborhood safety and age) and characteristics of the child (gender) in relation to the outdoor physical activity of preschool children.

\section{METHODS}

\section{Research Sample and Procedure}

The sample consisted of 156 parent-child dyads from urban areas (Table 1). In order to be suitable for participation in the study, parents were required to have at least one child aged between 2 and 6 years old. Respondents were selected based on their availability to researchers. The research included 156 children in total, out of which there where 79 (50.65\%) boys and $77(49.35 \%)$ girls. The average age of the total sample of children was $4.67(S D=1.19)$. The average age of boys was $4.75(S D=$ $1.11)$, while the average age of girls was $4.58(S D=1.57)$. The research included 105 mothers $(67.3 \%)$, whose average age was $35.16(S D=4.37)$, and 51 father $(32.7 \%)$, whose average age was $37.40(S D=3.64)$. There were collected data on the educational level of parents who filled in the questionnaire. The parents who participated in the research had mostly higher education. In total, $76(72.43 \%)$ mothers and 35 fathers $(68.62 \%)$ graduated from the faculty. On the other hand, three respondents (1.93\%) stated that they had a low parental income, while 84 of them had an average parental income (53.84\%), and 69 of them had a high parental income $(44.23 \%)$. The marital status of parents was examined as well. Out of 156 parents in total, only $2(1.28 \%)$ stated that they were divorced, while $0 \%$ was a single parent. The remaining $154(98.72 \%)$ were married (Table 1). 
Table 1. Descriptive characteristics of the sample $(n=156)$

\begin{tabular}{lr}
\hline Parents' sex & $105(67.3 \%)$ \\
Mother & $51(32.7 \%)$ \\
Father & \\
Parents' age (Mean \pm SD) & $35.16 \pm 4.37$ \\
Mother & $37.40 \pm 3.64$ \\
Father & \\
Parents' education & \\
Mother & $28(26.92 \%)$ \\
$\quad$ High school & $76(72.43 \%)$ \\
$\quad$ Faculty & $1(.65 \%)$ \\
Not answered & \\
Father & $14(27.45 \%)$ \\
$\quad$ High school & $35(68.63 \%)$ \\
Faculty & $2(3.92 \%)$ \\
Not answered & \\
Marital status & $154(98.72)$ \\
Married & $2(1.28 \%)$ \\
Divorced & $0(0 \%)$ \\
Single parent & \\
Parental income & $3(1.93 \%)$ \\
Low & $84(53.84 \%)$ \\
Average & $69(44.23 \%)$ \\
High & \\
Child's sex & $77(49.35 \%)$ \\
Female & $79(50.65 \%)$ \\
Male & \\
Child's age (Mean \pm SD) & $4.58 \pm 1.27$ \\
Female & $4.75 \pm 1.11$ \\
Male & \\
\hline Note Numbers in parentheses indicate the standard deviations. &
\end{tabular}

The participants were previously informed about the objectives of the research and guaranteed anonymity. The questionnaire required about 20 minutes to be filled in, and all the parents participated voluntarily without financial compensation.

\section{Research Instrument}

Given that cognitive skills, which are necessary to articulate meaningful responses in children under the age of 10, are underdeveloped, researchers typically use parental assessments of the child's behavior (Sallis, 1991). The questionnaire applied in the survey consisted of two parts. The first part referred to the examination of socio-demographic characteristics of the family and the degree of outdoor physical activity of children (Weir et al., 2006). The social-demographic characteristics of the family implied the following: parents' age, parents' educational level, a 
parental income and marital status, as well as the child's sex and age. Namely, the parents evaluated the frequency of various forms of physical activity of children in different situations (outside of the apartment/house, in the nearby park, walking or cycling, with adults in a nearby park or a playground). Responses were recorded on a 4-point scale with endpoints ranging from 1 (never) to 4 (always). Reliability of the scale was high (Cronbach's alpha $=.88)$.

The second part of the questionnaire referred to the examination of parental perception of neighborhood safety. This was done by using the Neighborhood Safety Subscale (NSS) of the Self-Care Checklist-Parent questionnaire, an instrument that was used in the previous studies (Pettit, Bates, Dodge, \& Meece, 1999). The NSS consisted of six statements with a five-point Likert format (from 1 - strongly disagree to 5 - strongly agree). For example: "Drug dealers are a problem in our neighborhood." The internal consistency of this scale was satisfactory (Cronbach's alpha $=.79$ ).

\section{Data Analysis / Data Analytic Plan}

Prior to hypothesis testing, Confirmatory Factor Analysis (CFA) was performed in the Lavaan software package, written for the $\mathrm{R}$ environment (Rosseel, 2012). After that, the correlation between the studied variables was calculated. The differences in the degree of outdoor physical activity between boys and girls were considered by using the $t$ test of independent samples. The moderated moderation, i.e. three-way interaction, was analyzed by using the PROCESS macro (Hayes, 2013) using SPSS 21, as follows: neighborhood safety, as perceived by the parent, was the predictor, the child's gender and the parents' age were the moderators, with the outdoor physical activity of the child being the criterion.

\section{RESULTS}

\section{Confirmatory Factor Analysis (CFA)}

Validity of the applied instrument was evaluated by Confirmatory Factor Analysis (CFA), which was performed in the Lavaan software package. The model compliance, or fit, was assessed by using the following indices (Kline, 2005): Chi-square $\left(\chi^{2}\right)$, root mean square error of approximation (RMSEA), standardized root mean residual (SRMR), comparative fit index (CFI), and the Tucker-Lewis index (TLI). The following values were considered indicators of acceptable fit: $\chi^{2} / \mathrm{df} \leq 3$, RMSEA < .10, SRMR <.08, CFI > .90, and TLI > .90 (Hopwood \& Donnellan, 2010; Kenny et al., 2014; Kline, 2005). Taking into account the more liberal criteria, the results showed that the empirical data were in agreement with the assumed model $\left(\chi^{2}=79.34, d f=34, p<.01\right.$, RMSEA $=$ $0.91, \mathrm{SRMR}=0.07, \mathrm{CFI}=0.93, \mathrm{TLI}=0.91$ ). 


\section{Descriptive Statistics}

Descriptive statistics and correlations between the examined variables are shown in Table 2. The correlation between the perceived neighborhood safety and the physical activity of children was statistically significant and of the expected direction $(r=.39)$. Also a significant correlation was obtained between the parents' age and the perceived neighborhood safety $(r=.16)$. No significant correlation was obtained between the parents' age and the estimated degree of physical activity of children.

The present study did not show any significant differences in the level of outdoor physical activity between boys $(M=11.84, S D=3.19)$ and girls $(M=11.89, S D=2.45)$ of preschool age $(t=-0.11, d f=154, p>.05)$ (Table 2).

Table 2. Correlations between the examined variables

\begin{tabular}{lcccccc}
\hline & 1 & 2 & 3 & 4 & M & SD \\
\hline 1. Gender of the child & 1 & & & & - & - \\
2. Neighbourhood safety & .03 & 1 & & & 20.23 & 4.42 \\
3. Physical activity of children & .01 & $.39^{* *}$ & 1 & & 11.87 & 2.83 \\
4. Age of the parents & -.11 & $.16^{*}$ & .03 & 1 & 35.89 & 4.27 \\
\hline \multicolumn{2}{c}{$p<.05 ;{ }^{* *} p<.01}$. & & & &
\end{tabular}

It was not possible to test the role of the marital status in perceiving the neighborhood safety, since majority of the surveyed parents $(98.72 \%)$ stated that they were married. It was possible to interpret this finding with the specificities of the national culture and the region. Therefore, further analysis was carried out independently of the factor of the parents' marital status.

Since a very small number of parents stated that had a low monthly income, there were tested the differences in the perceptions of the neighborhood safety between an average parental income on one side, and a high parental income on the other side. It was not found that the parents who had high parental income significantly more positively perceived neighborhood safety $(M=21.29, S D=4.11)$, in comparison to the parents with the average parental income $(M=20.50, S D=4.49), t=-1.14, d f=$ $153, p>.05$. The obtained result implied that the amount of monthly income in the Serbian social context is not related to parental beliefs about the neighborhood safety in social environment.

In order to examine the relationship between the parents' level of education and their observation of the neighborhood safety, the independent samples t-test was applied. According to the obtained results, there were no statistically significant differences in the perception of the neighborhood safety of mothers who completed secondary school $(M=19.27, S D=4.79)$, compared to mothers who completed the higher education $(M=20.60, S D=$ $4.56), t=-1.32, d f=102, p>.05$. When it came to education of fathers, it was also found that there were no significant differences in the perception of 
fathers with completed secondary school $(M=18.85, S D=3.97)$, compared to the fathers who completed higher education $(M=20.70, S D=3.89), t=-$ $1.47, d f=47, p>.05$.

\section{Testing the Moderated Moderation}

The triple interaction between parental perception of neighborhood safety, the gender of a child and the parents' age was obtained as significant (Table 3).

Table 3. Effects of neighbourhood safety, gender of the child and the parent age on outdoor physical activity of children

\begin{tabular}{lc}
\hline & $\begin{array}{c}\text { Outdoor physical activity } \\
\text { of children }\end{array}$ \\
\hline$R$ & $.47^{*}$ \\
$R^{2}$ & .22 \\
Gender of the child & -.19 \\
Neighbourhood safety & $.25^{* *}$ \\
Gender of the child X Neighbourhood safety & $-.23^{* *}$ \\
Age of parents & -.013 \\
Neighbourhood safety X Age of parents & .005 \\
Gender of the child X Age of parents & .014 \\
Neighbourhood safety X Gender of the child & $.036^{*}$ \\
X Age of parents & \\
\hline
\end{tabular}

Note: ${ }^{*} \mathrm{p}<, 05 ;{ }^{* * *} \mathrm{p}<, 01$

In other words, the moderating effect of gender on the relation between parental perception of neighborhood safety and the physical activity of children depended on the parents' age. Based on the Johnson-Neyman testing of significance of the region, it was obtained that the interaction between the perceived neighborhood safety and the gender of the child significantly affected the physical activity of children in case when the parents' age scores were below 36.86. Above this age of parents, children gender did not moderate the perception effect of the neighborhood safety for outdoor physical activity of children.

The results indicate that the relation between parental perception of neighborhood safety and frequency of outdoor physical activity of children was significantly moderated by the gender of children in the case of belowaverage age of parents. Male children of preschool age with parents`age scores below 36.86, who positively assessed the neighborhood safety were more prone to physical activity in the open. On the other hand, in the case of female children with parents of below-average age $(\mathrm{M}-1 \mathrm{SD}=36.86)$, the perceived neighborhood safety did not provide any level of physical activity (Figure 1a). 
Parents age: below average $(\mathrm{M}-1 \mathrm{SD}=31.62)$

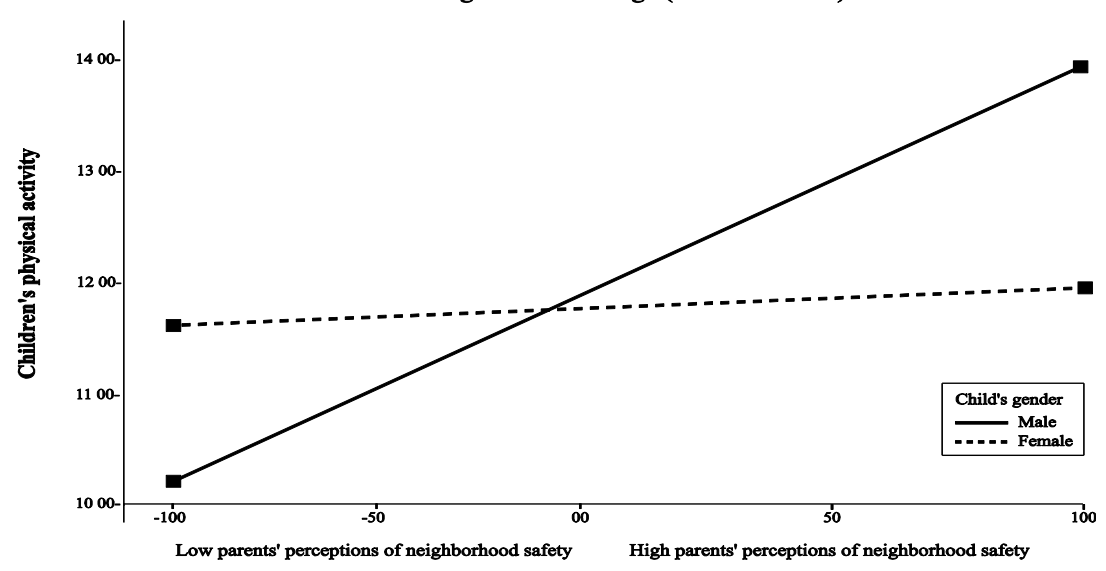

Fig. la The moderating role of the child's gender and the parent age in the relationship between neighbourhood safety and the outdoor physical activity of children

Girls of preschool age with the above average age $(\mathrm{M}+1 \mathrm{SD}=$ 40.16) of parents who positively assessed the neighborhood safety, express higher levels of physical activity in the neighborhood (Figure 1b).

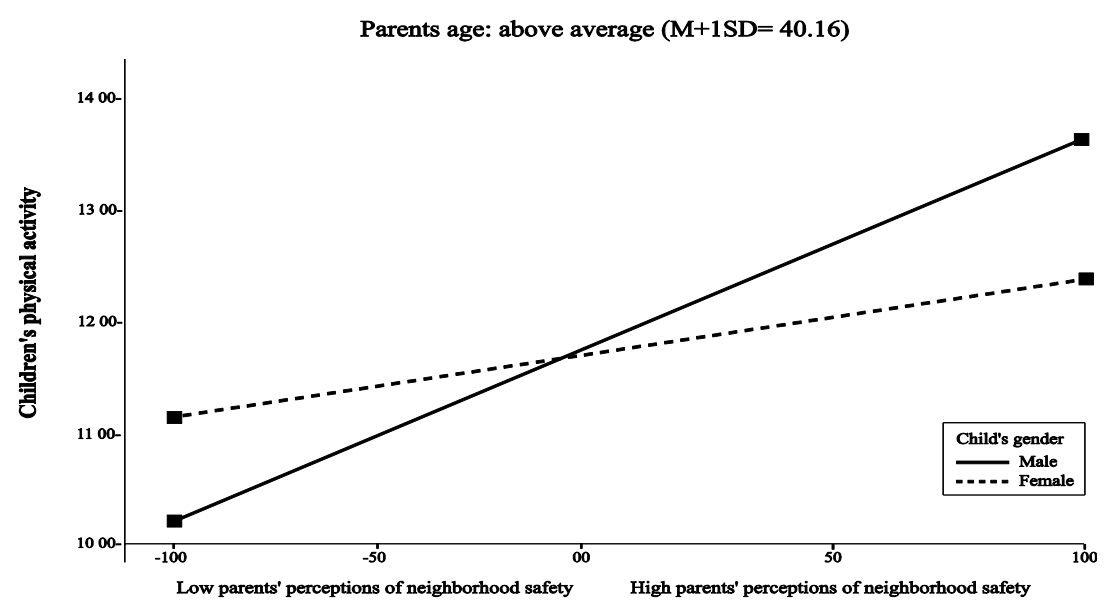

Fig. $1 b$ The moderating role of the child's gender and the parent age in the relationship between neighbourhood safety and the outdoor physical activity of children

Generally speaking, parental perceptions of neighborhood safety predicted the level of outdoor physical activity for their children. Also, boys whose parents negatively assessed the neighborhood safety were rarely engaged in physical activity, regardless of the age of the parents. 


\section{DISCUSSION AND CONCLUSION}

The main result of this study suggests that the relationship between parental perception of neighborhood safety and the frequency of outdoor physical activity of preschool children is ambiguous. The findings of this study support other studies which have shown that parental perceptions of neighborhood safety do not always directly affect the physical activity of children, but this relationship depends on the other factors as well (Craver et al., 2010). In this way, an insight has been obtained in the conditions that shape the effects of parental assessments of neighborhood safety on the prevalence of physical activity of preschool children.

The results of this paper suggest that the male preschoolers whose parents positively assess the neighborhood safety, but who are also of younger age, spend more time engaged in the outdoor physical activities. Thus, although the positive assessment of neighborhood safety by parents represents a significant predictor of the children's outdoor physical activity, the interaction of the child's gender and the parent age still significantly affects this relationship. It is possible that the young parents of male children also prefer physical activities, which in turn affects their children (Irwin et al., 2005). Previous studies (Zecevic et al., 2010) have shown that the parents' age is a significant predictor of physical activity of the preschool children, i.e. that the children of older parents are less active.

On the other hand, it is found that the assessment of neighborhood safety by younger parents generally do not provide for outdoor physical activity of girls of the preschool age. A parallel can be drawn with the research which has shown that the male preschoolers are significantly more physically active than the female preschoolers (Hinkley et al., 2008; Tucker, 2008). In the context of different socialization of boys and girls, it can be assumed that there are differences in the way parents relate to the physical activity of their sons and daughters, and encourage more intensely physical activity of male children. While parents try to protect female children by encouraging them to play at home, boys are more encouraged to play outside, because male children are perceived as more resistant (Cherney and London, 2006; Gomez et al., 2004).

A number of authors believe that children's physical activity is also affected by social factors, which in younger age are directly linked to the attitude of parents towards physical activity (Hinkley et al., 2008; Tucker, 2008). In this regard, the difference in the way in which boys and girls are encouraged by their parents to play with different toys and sports equipment can also lead to differences in motor performances between boys and girls, and hence to a reduced level of physical activity of girls, even to the reduced levels of encouragement for physical activity both by parents and the environment. The above has also been confirmed by the findings of this study, according to which, in the case of younger parents, the assessment of neighborhood safety does not include any physical 
activity of female children of the preschool age. This finding may indicate that younger parents of male children are more permissive and more likely to encourage their children to play outdoors. This indicates that physical activity-related parenting behaviors, as well as the styles of upbringing vary depending on the child's gender (Jago et al., 2011).

It is possible that young parents of female children are rarely willing to allow them to play outdoors, regardless of their neighborhood safety assessment and attitude towards physical activity. In other words, there is a group of female preschool children whose parents do not encourage physical activity of their children in a nearby park or playground, even though they positively assess the neighborhood safety. The positive perception of neighborhood safety by younger parents is unlikely to influence actual physical activity of female children.

This is one of the few studies dealing with the moderators of relationship between the parents' assessments of neighborhood safety and the outdoor physical activity of preschool children. A better understanding of parental care and other influences acting on the children's activities and free play can be of great importance for the development of strategies and policies aimed at promoting physical activity among this important target group. Studies in this area are particularly important in Serbia, having in mind the lack of similar research in this country.

The general conclusion of this paper points to the importance of systematic work on the improvement of neighborhood safety, and that these efforts should be also involved in the public health policy. On the other hand, it seems that social campaigns should be devised aiming at reconsidering parents' behavior towards their children and raising awareness of the need for equal encouragement of physical activity of children of different genders.

From the perspective of public health, a promotion of the neighborhood safety will have a positive impact on children's active freeplay. In order to increase the opportunities for the children's physical activity in local communities, it is important to devise social campaigns for parents, which will be focused on actual risks associated with the outdoor physical activities, and provide children with specific knowledge and skills that enable them to play in their own neighborhood safely (Veitch et al., 2010). Moreover, it is possible to achieve this by finding appropriate locations for parks and playgrounds, as well as by providing the equipment that meets the needs of children of different ages.

Although this study sheds the light on some significant issues, when it comes to the relation between the variables examined, it raises additional questions, such as the role of the parents' age in encouraging the children's physical activity, which may be the subject of the future research. It should be emphasized that it is useful to introduce some objective measures that can help to quantify the prevalence of physical 
activity among Serbian pre-school children. This is particularly important because there is a possibility that parents overestimate the presence of the outdoor activities of their children. On the other hand, it can be useful to consider the objective indicators of neighborhood safety both in urban and rural communities in Serbia.

Given that the data have been collected in the urban environment, it is possible that the results are not representative, and that it is necessary to cover areas of low socio-economic status, which are particularly suitable grounds for the outdoor physical activity of children (Carver et al., 2008). In this regard, it would be useful to carry out similar research on a larger sample, which may have significant implications on policies and practices of public health.

\section{REFERENCES}

Atan, T., Uysal, T., Cicek, G. (2013). Parents' attitudes towards attending physical education oriented games of their children in kindergarten. International Journal of Academic Research Part B, 5(2), 250-254.

Australian Government Department of Helth and Ageing (2004). Australian physical activity recommendations for children and youth. Canberra: Australian Government.

Bailey, R. (2005). Evaluating the relationship between physical education, sport and social inclusion. Educational Review, 57(1), 71-90.

Blakely, K. (1994). Parents' conceptions of social dangers to children in the urban environment. Children's Environment, 11(1), 16-25.

Boreham, C., \& Riddoch, C. (2001). The physical activity, fitness and health of children. Journal of Sports Sciences, 19(12), 915-929.

Burman, M., Brown, J., Tisdall, J., Batchelor, S. (2000). A View from the Girls: Exploring Violence and Violent Behavior, Economic \& Social Research Council. Available from:/http://www1.rhbnc.ac.uk/sociopolitical-science/ VRP/Findings/rfburman.PDFS (accessed 22 August 2016).

Carlin, J., Stevenson, M., Roberts, I., Bennett, C., Gelman, A., Nolan, T., (1997). Walking to school and traffic exposure in Australian children. Australian and New Zealand Journal of Public Health 21(3), 286-292.

Carver, A., Timperio, A., \& Crawford, D. (2008). Playing it safe: The influence of neighbourhood safety on children's physical activity-A review. Health \& Place, 14(2), 217-227.

Carver, A., Timperio, A., Hesketh, K., \& Crawford, D. (2010). Are children and adolescents less active if parents restrict their physical activity and active transport due to perceived risk?. Social science \& Medicine, 70(11), 1799-1805.

Certain, L. K., \& Kahn, R. S. (2002). Prevalence, correlates, and trajectory of television viewing among infants and toddlers. Pediatrics, 109(4), 634-642.

Cherney, I. D., \& London, K. (2006). Gender-linked differences in the toys, television shows, computer games, and outdoor activities of 5-to 13-year-old children. Sex Roles, 54(9-10), 717-726.

Datar, A., Nicosia, N., \& Shier, V. (2013). Parent perceptions of neighborhood safety and children's physical activity, sedentary behavior, and obesity: evidence from a national longitudinal study. American Journal of Epidemiology, 1-9. 
Davison, K. K., \& Lawson, C. T. (2006). Do attributes in the physical environment influence children's physical activity? A review of the literature. International Journal of Behavioral Nutrition and Physical Activity 3, 1-17.

Đorđić, V. (2006). Fizička aktivnost predškolske dece [Physical Activity of Preschoolers]. Zbornik radova: Antropološke karakteristike i sposobnosti predškolske dece, Univerzitet u Novom Sadu, Fakultet fizičke kulture, str. 331-360.

Emck, C., Bosscher, R., Beek, P., \& Doreleijers, T. (2009). Gross motor performance and self-perceived motor competence in children with emotional, behavioural, and pervasive developmental disorders: a review. Developmental Medicine \& Child Neurology, 51(7), 501-517.

Evans, J. (2004). Where do children play? Children Australia, 25(2),35-40.

Ginsburg, K.R. (2007). The Importance of Play in Promoting Healthy Child Development and Maintaining Strong Parent - Child Bonds. Pediatrics, 119(1), 182-191.

Gomez, J. E., Johnson, B. A., Selva, M., \& Sallis, J. F. (2004). Violent crime and outdoor physical activity among inner-city youth. Preventive Medicine, 39(5), 876-881.

Grigsby-Toussaint, D. S., Chi, S. H., \& Fiese, B. H. (2011). Where they live, how they play: Neighborhood greenness and outdoor physical activity among preschoolers. International Journal of Health Geographics, 10(1), 1-10.

Harris, K. C., Kuramoto, L. K., Schulzer, M., \& Retallack, J. E. (2009). Effect of school-based physical activity interventions on body mass index in children: a meta-analysis. Canadian Medical Association Journal, 180(7), 719-726.

Hayes, A. F. (2013). Introduction to Mediation, Moderation, and Conditional Process Analysis: A Regression-Based Approach. New York: The Guilford Press.

Hill, J. O., \& Peters, J. C. (1998). Environmental contributions to the obesity epidemic. Science, 280(5368), 1371-1374.

Hillman, M., Adams, J., Whitelegg, J. (1990). One Flase Move, a Study of Children's Independent Mobility. Policy Studies Institute, London.

Hinkley, T., Crawford, D., Salmon, J., Okely, A. D., \& Hesketh, K. (2008). Preschool children and physical activity: a review of correlates. American journal of preventive medicine, 34(5), 435-441.

Hopwood, C. J., \& Donnellan, M. B. (2010). How should the internal structure of personality inventories be evaluated? Personality and Social Psychology Review, 14(3), 332-346.

Humbert, M.L., Chad, K.E., Spink, K.S., et al. (2006). Factors that influence physical activity participation among high and low SES youth. Quality Health Research, 16(4), 467-483.

Irwin, J. D., He, M., Bouck, L. M., Tucker, P., \& Pollett, G. L. (2005). Irwin, J. D., He, M., Bouck, L. M. S., Tucker, P., \& Pollett, G. L. (2005). Preschoolers' physical activity behaviours: parents' perspectives. Canadian Journal of Public Health/Revue Canadienne de Sante'e Publique, 299-303.

Jago, R. D., Brockman, R., Page, A. S., Thompson, J. L., \& Fox, K. R. (2011). Parenting styles, parenting practices, and physical activity in 10-to 11-year olds. Preventive medicine, 52(1), 44-47.

Kamenov, E. (2006). Vaspitanje predškolske dece [Education of Preschool children]. Beograd: Zavod za udžbenike i nastavna sredstva.

Karsten, L. (2005). It all used to be better? Different generations on continuity and change in urban children's daily use of space. Children's Geographies, 3, 275-290.

Kenny, D. A., Kaniskan, B., \& McCoach, D. B. (2014). The performance of RMSEA in models with small degrees of freedom. Sociological Methods \& Research. 
Klesges, R. C., Eck, L. H., Hanson, C. L., Haddock, C. K., \& Klesges, L. M. (1990). Effects of obesity, social interactions, and physical environment on physical activity in preschoolers. Health Psychology, 9(4), 435-449.

Kline, R. (2011). Principles and Practice of Structural Equation Modeling. New York: The Guilford Press.

Matthews, H. (1995). Living on the edge: children as 'outsiders'. Tijdschrift voor Economische en Sociale Geografie, 86(5), 456-466.

Mullan, E. (2003). Do you think that your local area is a good place for young people to grow up? The effects of traffic and car parking on young people's views. Health \& Place, 9, 351-360.

National Association for Sport and Physical Education, (2004). Physical activity for children: A statemen of guidelines (2nd ed.). Reston, VA: NASPE Publications.

Okely, A. D., Trost, S. G., Steele, J. R., Cliff, D. P., \& Mickle, K. (2009). Adherence to physical activity and electronic media guidelines in Australian pre-school children. Journal of Paediatrics and Child Health, 45(1-2), 5-8.

Pate, R.R., Baranowski, T., Dowda, M., Trost, S.G. (1996). Tracking of physical acitivy in young children. Med. Sci. Sport Exerc., 28, 92-96.

Pettit, G. S., Bates, J. E., Dodge, K. A., \& Meece, D. W. (1999). The impact of after-school peer contact on early adolescent externalizing problems is moderated by parental monitoring, perceived neighborhood safety, and prior adjustment. Child Development.

Rosseel, Y. (2012). lavaan: An R package for structural equation modeling. Journal of Statistical Software, 48(2), 1-36.

Sallis, J. F. (1991). Self-report measures of children's physical activity. Journal of School Health, 61(5), 215-219.

Sallis, J. F., Johnson, M. F., Calfas, K. J., Caparosa, S., \& Nichols, J. F. (1997). Assessing perceived physical environmental variables that may influence physical activity. Research Quarterly for Exercise and Sport, 68(4), 345-351.

Sallis, J. F., Nader, P. R., Broyles, S. L., Berry, C. C., Elder, J. P., McKenzie, T. L., \& Nelson, J. A. (1993). Correlates of physical activity at home in Mexican-American and Anglo-American preschool children. Health Psychology, 5, 390-398.

Strong, W., Malina, R., Blimkie, C., Daniels, S., Dishman, R., Gutin, B., Hergenroeder, A., Must, A., Nixon, P., Pivarnik, J., Rowland, T., Trost, S., Trudeau, F. (2005). Evidence based physical activity for school-age youth. Journal of Pediatrics 146(6), 723-727.

Sturza Milić, N. (2008). Uticaj porodice na motoričku aktivnost i darovitost predškolske dece $u$ zavisnosti od pola [The influence of the family on the motor activity and the giftedness of preschool children depending on gender]. Available from http://www.uskolavrsac.edu.rs/Novi\%20sajt\%202010/Dokumenta/Izdanja/14 $\% 20$ Okrugli\%20sto/SturzaN\%20-\%2048.pdf. Accessed 2.12.16.

Tandy, C. (1999). Children's diminishing play space: a study of intergenrational changes in children's use of their neighbourhoods. Australian Geographical Studies, 37(2), 154-162.

Timperio, A., Crawford, D., Telford, A., Salmon, J. (2004). Perceptions about the local neighbourhood and walking and cycling among children. Preventive Medicine, 38, $39-47$.

Tomkinson, G., Leger, A., Olds, T., Cazorla, G., (2003). Secular trends in the performance of children and adolescents (1980-2000): an analysis of 55 studies of the $20 \mathrm{~m}$ shuttle run tes in 11 countries. Sports Medicine, 33(4). 285-300.

Tranter, P., \& Pawson, E. (2001). Children's access to local environments: a casestudy of Christchurch, New Zealand. Local Environment, 6(1), 27-48. 
Tucker, P. (2008). The physical activity levels of preschool-aged children: A systematic review. Early Childhood Research Quarterly, 23(4), 547-558.

Valentine, G., McKendrick, J. (1997). Children's outdoor play: exploring parental concerns about children's safety and the changing nature of childhood. Geoforum, 28(2), 219-235.

Veitch, J., Bagley, S., Ball, K., \& Salmon, J. (2006). Where do children usually play? A qualitative study of parents' perceptions of influences on children's active free-play. Health \& Place, 12(4), 383-393.

Veitch, J., Salmon, J., \& Ball, K. (2010). Individual, social and physical environmental correlates of children's active free-play: a cross-sectional study. International Journal of Behavioral Nutrition and Physical Activity, 7(1), 1-10.

Wardle, J., Guthrie, C. A., Sanderson, S., \& Rapoport, L. (2001). Development of the children's eating behaviour questionnaire. Journal of Child Psychology and Psychiatry, 42(7), 963-970.

Weir, L. A., Etelson, D., \& Brand, D. A. (2006). Parents' perceptions of neighborhood safety and children's physical activity. Preventive Medicine, 43(3), 212-217.

Zecevic, C. A., Tremblay, L., Lovsin, T., \& Michel, L. (2010). Parental influence on young children's physical activity. International Journal of Pediatrics, 1-9.

\title{
БЕЗБЕДНОСТ СУСЕДСТВА И ФИЗИЧКА АКТИВНОСТ ДЕЦЕ ПРЕДШКОЛСКОГ УЗРАСТА: МОДЕРАТОРСКА УЛОГА ПОЛА ДЕТЕТА И СТАРОСТИ РОДИТЕЉА
}

\author{
Стефан Нинковић, Станислава Марић Јуришин, Борка Малчић \\ Универзитет у Новом Саду, Филозофски факултет, Одсек за педагогију, \\ Нови Сад, Србија
}

\section{Резиме}

Ране године живота детета кључне су у постављану темеља за његов даљи развој. У ери пренаглашене урбанизације, алијенације и доминације масовних медија, све мање деце време проводи бавећи се физичком активношћу на отвореном. Безбедност суседства представља потенцијално важан, још увек недовољно истражен, фактор социјалне средине који утиче на физичку активност деце. Једна од примарних карактеристика деце предшколског узраста јесте да су веома активна, при чему је управо физичка активност суштински фактор у задовољавању њихове потребе за кретањем. И поред тога, све је већи број деце предшколског узраста (од 3 године до 5 година) која проводе више времена у коришћењу електронских медија (телевизија, компјутер, видео-игре...) него у бављењу физичком активношћу. Будући да су родитељи препознати као носиоци дечије физичке активације, те да степен њихове бриге може значајно да утиче и на могућности деце за слободну игру, циљ нашег истраживања био је да се испитају ефекти родитељских перцепција безбедности суседства на физичку активност на отвореном деце предшколског узраста у Србији. Узорак је чинило 156 родитеља из урбане градске средине. Резултати показују да постоји корелација између опажене безбедности краја и физичке активности деце, те да је статистички значајна и очекиваног смера. Такође, добијена је значајна повезаност између старости родитеља и опажене безбедности суседства. Између старости родитеља и процењеног нивоа физичке активности деце 
није добијена значајна корелација. У овом истраживању нису добијене значајне разлике у нивоу физичке активности на отвореном између дечака и девојчица предшколског узраста. Такође, резултати показују модераторски ефекат пола на однос између родитељских перцепција безбедности краја и физичке активности деце зависи од старости родитеља. Деца предшколског узраста мушког пола која имају млађе родитеље који позитивније процењују безбедност суседства склонија су физичкој активности на отвореном. С друге стране, у случају деце женског пола која имају родитеље исподпросечне старости, опажена безбедност краја не предвиђа ниво физичке активности. Родитељске перцепције безбедности суседства, уопштено посматрано, предвиђају ниво физичке активности њихове деце на отвореном. Ово је једна од ретких студија које се баве модераторским односом родитељских процена безбедности суседства и физичке активности на отвореном деце предшколског узраста. Боље разумевање родитељске бриге и осталих утицаја на дечију активност и слободну игру може бити од великог значаја за развој стратегија и политика које за циљ имају промовисање физичке активности међу овом значајном циљном групом. Општи закључак овог рада био би да је важно да се систематски ради на унапређењу безбедности суседства и да се та настојања укључе у политику јавног здравља. 